\title{
Cow, Farm, and Management Factors During the Dry Period that Determine the Rate of Clinical Mastitis After Calving
}

\author{
M. J. Green, ${ }^{\star} \dagger^{1}$ A. J. Bradley, $\ddagger$ G. F. Medley,§ and W. J. Browne $†$ \\ *School of Veterinary Medicine and Science, University of Nottingham, Sutton Bonington, LE12 5RD, United Kingdom \\ †School of Mathematical Sciences, University of Nottingham, Nottingham, NG7 2RD, United Kingdom \\ $\ddagger$ Department of Clinical Veterinary Science, University of Bristol, Bristol, BS40 5DT, United Kingdom \\ $\S$ Ecology and Epidemiology Group, Department of Biological Sciences, University of Warwick, Coventry, CV4 7AL, United Kingdom
}

\begin{abstract}
The purpose of the research was to investigate cow characteristics, farm facilities, and herd management strategies during the dry period to examine their joint influence on the rate of clinical mastitis after calving. Data were collected over a 2-yr period from 52 commercial dairy farms throughout England and Wales. Cows were separated for analysis into those housed for the dry period (8,710 cow-dry periods) and those at pasture (9,964 cow-dry periods). Multilevel models were used within a Bayesian framework with 2 response variables, the occurrence of a first case of clinical mastitis within the first $30 \mathrm{~d}$ of lactation and time to the first case of clinical mastitis during lactation. A variety of cow and herd management factors were identified as being associated with an increased rate of clinical mastitis and these were found to occur throughout the dry period. Significant cow factors were increased parity and at least one somatic cell count $\geq 200,000$ cells $/ \mathrm{mL}$ in the $90 \mathrm{~d}$ before drying off. A number of management factors related to hygiene were significantly associated with an increased rate of clinical mastitis. These included measures linked to the administration of drycow treatments and management of the early and late dry-period accommodation and calving areas. Other farm factors associated with a reduced rate of clinical mastitis were vaccination with a leptospirosis vaccine, selection of dry-cow treatments for individual cows within a herd rather than for the herd as a whole, routine body condition scoring of cows at drying off, and a pasture rotation policy of grazing dry cows for a maximum of $2 \mathrm{wk}$ before allowing the pasture to remain nongrazed for a period of $4 \mathrm{wk}$. Models demonstrated a good ability to predict the farm incidence rate of clinical mastitis in a given year, with model predictions explaining over $85 \%$ of the variability in the observed
\end{abstract}

Received February 13, 2007.

Accepted March 30, 2007.

${ }^{1}$ Corresponding author: martin.green@nottingham.ac.uk data. The research indicates that specific dry-period management strategies have an important influence on the rate of clinical mastitis during the next lactation. Key words: mastitis, dry period, dairy cow, Bayesian multilevel model

\section{INTRODUCTION}

The importance of the dry (nonlactating) period in the dynamics of IMI in dairy cattle is well established (Neave et al., 1950; Oliver and Mitchell, 1983; Smith et al., 1985; Todhunter et al., 1991; Bradley and Green, 2000; Green et al., 2002a). Intramammary infections that are present during the dry period can be partitioned into those that were carried into the dry period from the previous lactation (existing infections), and those that enter between the time of drying off and calving (new infections; Bradley and Green, 2004).

The probability of a new dry-period IMI is influenced by the rate of exposure to potential pathogens (e.g., from the environment), factors that affect an individual cow's susceptibility to infection (Dingwell et al., 2004), and the effectiveness of protection from medical interventions such as antibiotic dry-cow therapy or teat sealants (Bradley and Green, 2001; Berry and Hillerton, 2002; Huxley et al., 2002; Robert et al., 2006). Differences have been identified in patterns of IMI during the dry period between farms, and over time (Dingwell et al., 2004; Green et al., 2005), but the reasons for such differences have not yet been quantified. A recent metaanalysis of spontaneous IMI occurring during the dry period concluded that to understand the benefits of alternative dry-cow treatment regimens, more research is needed into risk factors for new IMI during the dry period (Robert et al., 2006). Causes of variability in the risk of infection between farms are an important but poorly defined element of dry-period mastitis control (Huijps and Hogeveen, 2007).

Compared with an uninfected mammary gland, glands that are infected during the dry period are at a greater risk of clinical mastitis $(\mathbf{C M})$ during the next 


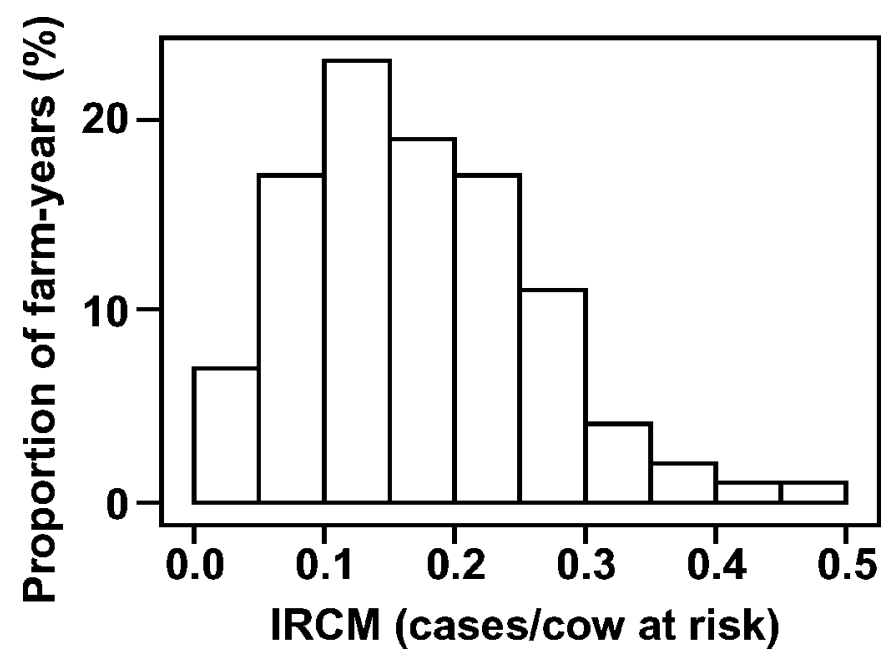

Figure 1. Incidence rates of the first case of clinical mastitis (IRCM; cases per cow at risk) in the first $30 \mathrm{~d}$ of lactation, for each of 103 farm-years, for cattle housed during the dry period.

lactation (Bradley and Green, 2000; Green et al., 2002a). Furthermore, CM in cows with an IMI in the previous dry period occurs at a faster rate after calving than $\mathrm{CM}$ in cows identified as uninfected during the dry period (Green et al., 2002a). Therefore, IMI control strategies during the dry period are likely to influence the rate of $\mathrm{CM}$ after calving.

The aim of this research was to investigate concurrently cow characteristics, farm facilities, and herd management strategies during the dry period to examine their joint influence on the rate of $\mathrm{CM}$ after calving. Interest was focused on identifying determinants of the rate of $\mathrm{CM}$ and to assess the extent to which models of these determinants could be used to predict CM in the first $30 \mathrm{~d}$ of lactation.

\section{MATERIALS AND METHODS}

\section{Farm Selection}

Fifty-two commercial dairy farms located throughout England and Wales were included in the study. During the study period, the median herd size was 156 cows and the median milk yield was $8,500 \mathrm{~kg} / \mathrm{cow}$ per year. The median incidence rate of cows affected on one or more occasion with CM was 0.45 cases per cow-year and the overall median incidence rate of $\mathrm{CM}$ was 0.82 cases per cow-year. The median rolling annual bulk milk SCC was 198,000 cells $/ \mathrm{mL}$. This cohort of herds was selected following participation in an earlier research project (Green et al., 2007) because of notable heterogeneity in the rate of $\mathrm{CM}$ during lactation and the availability of high-quality cow, farm, and management information over a 2 -yr period. The variation in the rates of $\mathrm{CM}$ on these farms is illustrated in Figures 1

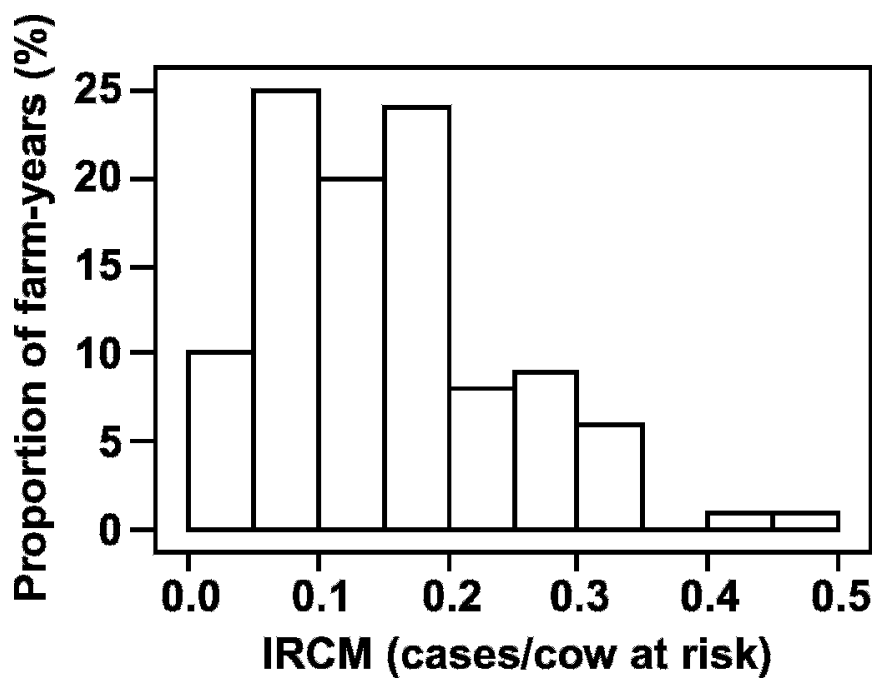

Figure 2. Incidence rates of the first case of clinical mastitis (IRCM; cases per cow at risk) in the first $30 \mathrm{~d}$ of lactation, for each of 104 farm-years, for cattle at pasture during the dry period.

and 2 (the incidence rates of $\mathrm{CM}$ in the first $30 \mathrm{~d}$ of lactation) and in Figures 3 and 4 (Kaplan-Meier survival curves) for individual farms for each year of the study period.

\section{Description of the Data}

Data were collected from all farms by trained researchers over a 2-yr period from May 2003 to May 2005. To characterize farm facilities and management policies, data were obtained from farmer interviews and through on-farm observation, using structured, pretested questionnaires. Information from questionnaires was collected in May or June 2004 (for yr 1) and again in May or June 2005 (for yr 2). Observation visits were also carried out annually and consisted of an inspection of all dry-period facilities. The information collected was in the following categories: general farm information (e.g., herd size, yield, breed), vaccination protocols, staffing level and work patterns, cow groups and dates of movement between groups, bedding types (storage, quantities used, and methods of application and clean out), cow nutrition and water (e.g., composition of diets, methods of provision, feed access, cow groups), dry-cow housing (e.g., types, dimensions, stocking rates, lying areas, loafing areas, cleaning out procedures, slurry handling, disinfection, ventilation, drainage, floor grip), dry-cow pasture (e.g., type of pasture, methods of rotation, stocking density, use and maintenance of tracks and gateways), calving cow housing (types such as individual boxes, yards or pasture, dimensions, stocking rates, lying areas, loafing areas, cleaning out proce- 


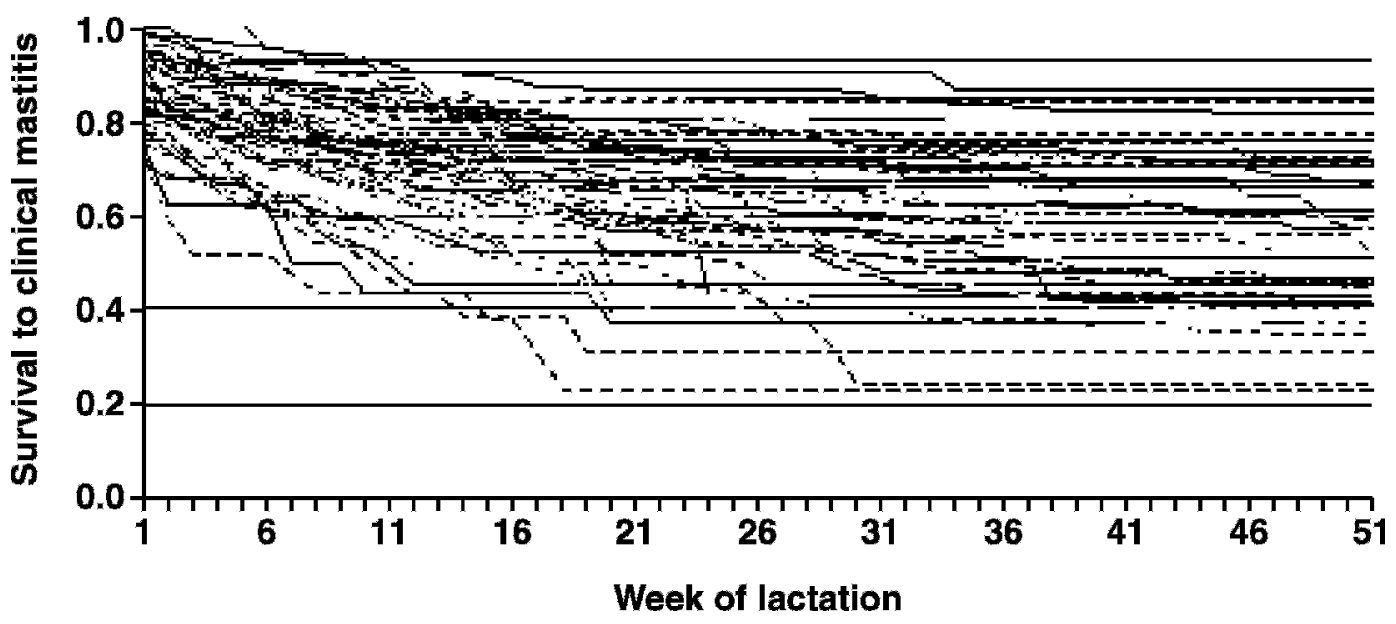

Figure 3. Kaplan-Meier survival curves illustrating the heterogeneity in cow survival times to the first case of clinical mastitis after calving, in each of 103 farm-years, for cattle housed during the dry period.

dures and slurry handling, disinfection, ventilation, drainage, floor grip), procedures used at drying off (e.g., preparation of the cow and teats, products used, treatment regimens used), procedures for calving and recently calved cows (e.g., composition of diets, methods of provision, feed access, cow groups, calf suckling period, postcalving milking policy, use of California Mastitis Test), and methods of fly control (e.g., timing of use, products used, groups of cattle for application).

If a management policy changed during the year, the date of the change was recorded and the appropriate data used for each cow-dry period. Most information gathered could be assessed objectively but in a few instances subjective measurements were included, such as the standard of ventilation. In these cases, broad categories were used (e.g., poor, adequate, or good) and standard operating procedures were used to determine when different categories would apply, to ensure consistency of categorization.

Cow information was obtained from a national milk recording body (National Milk Records, Chippenham, United Kingdom). Dates of calving, milk recording, and drying off were collated as well as parity, milk yield, milk constituents, and SCC. Dates of CM were obtained directly from farm records.

Dry periods included in the analysis were from cows that were dried off after May 2003 and that calved before May 2005. All cows had a minimum opportunity of $30 \mathrm{~d}$ of lactation to be considered for analysis. Cows could calve twice in the 2-yr period and thus have 2 dry

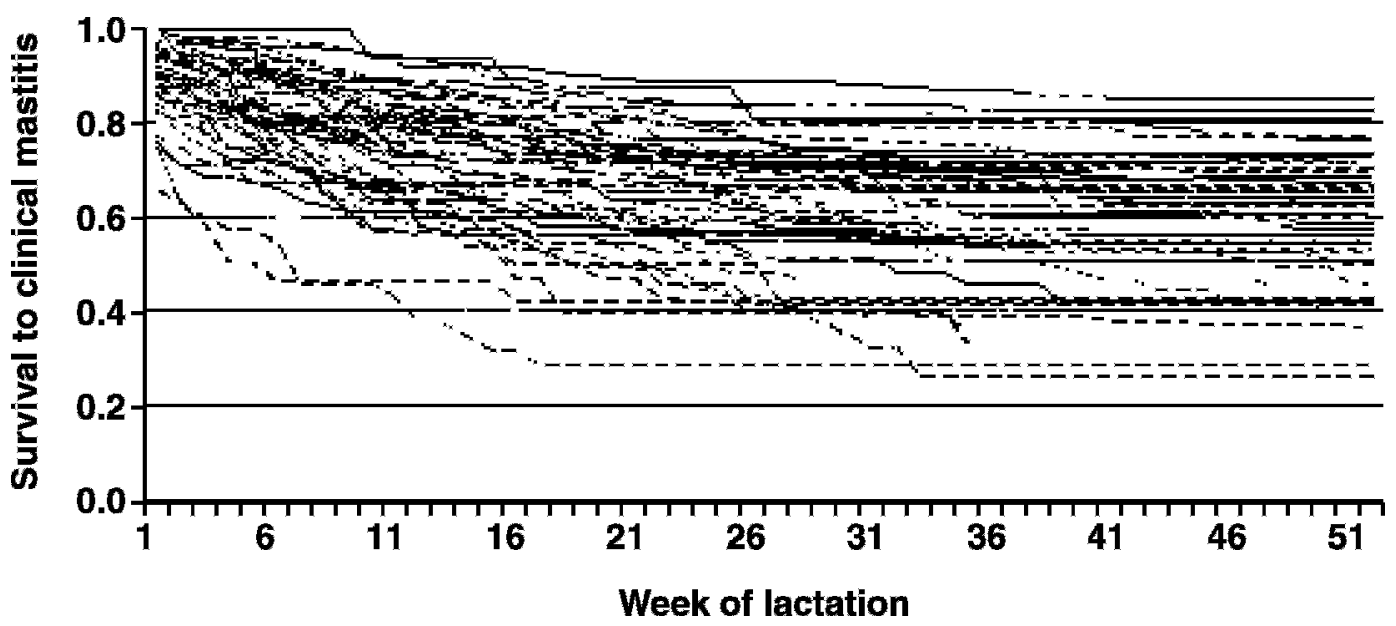

Figure 4. Kaplan-Meier survival curves illustrating the heterogeneity in cow survival times to the first case of clinical mastitis after calving, in each of 104 farm-years, for cattle at pasture during the dry period. 
periods included in the study. Analysis was conducted separately for cows housed during the dry period and for those at pasture during the dry period because different sets of management factors were applicable (and thus it was considered that different biological processes were being investigated). Cows that had a split dry period (partly housed and partly at pasture), were analyzed in different ways. First, they were omitted from the analyses altogether; second, they were included as subjects in both categories; and third, they were included in both categories but with an indicator variable "part housed/pasture." No important differences were found between model results or in biological inferences, and the latter method was chosen to estimate final model parameters. Cows calving for the first time were included in the analysis with precalving milk data categorized as "missing."

\section{Statistics and Analysis}

Cow and farm data were transferred to a database (Access 2003, Microsoft Corp., Redmond, WA) and all fields checked for unusual or impossible entries. Data fields were coded as categorical or continuous as appropriate and data transformations carried out for continuous data to normalize distributions when necessary. Cow and farm data were combined such that relevant farm information was related to the correct cow-dry period.

The outcome variable of interest was the occurrence of CM (first case in lactation) for each cow. Clinical mastitis was identified by herdpersons and was defined as visible changes to the milk such as clots, flakes, or watery milk, or changes to the udder such as swelling or heat. Clinical mastitis was investigated as a first occurrence within $30 \mathrm{~d}$ of calving (FCM30; Bernoulli response, 1 or 0 ) or as a time (wk) to the first occurrence during lactation (discrete time survival response). The data structure was hierarchical, consisting of a dry period for each cow (cow-dry period), within a 12-mo time span on a farm (farm-year), within a farm. Initial analysis consisted of descriptive statistics and graphical assessments. Conventional Kaplan-Meier survival curves (Collett, 1994) were constructed to provide a visual display of the different rates of CM during lactation between farm-years. A cow was considered to have "failed" in the week of the first case of CM and then was no longer considered in the risk group. Cows were censored at the end of a lactation or at the end of the study period, whichever occurred sooner.

Multilevel (random effects) models (Goldstein, 1995) were specified so that correlations within the data (cowdry periods within years within farms) were accounted for appropriately. Model specifications were
1. First case of clinical mastitis within $30 \mathrm{~d}$ of calving:

$$
\begin{aligned}
& \mathrm{FCM}_{30} 0_{\mathrm{ijk}}(1=\mathrm{CM}, 0=\text { no } \mathrm{CM}) \\
& \sim \text { Bernoulli probability }\left(\text { mean }=\pi_{\mathrm{ijk}}\right) \\
& \operatorname{Logit}\left(\pi_{\mathrm{ijk}}\right)=\alpha+\beta_{1} \mathrm{X}_{\mathrm{ijk}}+\beta_{2} \mathrm{X}_{\mathrm{jk}}+\beta_{3} \mathrm{X}_{\mathrm{k}}+\mathrm{v}_{\mathrm{k}}+\mathrm{u}_{\mathrm{jk}} \\
& \mathrm{v}_{\mathrm{k}} \sim \text { normal distribution }\left(0, \sigma_{\mathrm{v}}^{2}\right) \\
& \mathrm{u}_{\mathrm{jk}} \sim \text { normal distribution }\left(0, \sigma_{\mathrm{u}}^{2}\right)
\end{aligned}
$$

where the subscripts $\mathrm{i}, \mathrm{j}$, and $\mathrm{k}$ denote the ith cowdry period, the jth farm-year of study, and the kth farm, respectively; $\pi_{\mathrm{ijk}}$ the fitted probability of FCM30 for cow-dry period i of year $j$ on farm $\mathrm{k} ; \alpha$ the regression intercept; $\mathrm{X}_{\mathrm{ijk}}$ the vector of covariates at cow-dry period level; $\beta_{1}$ the coefficients for covariates $\mathrm{X}_{\mathrm{ijk}} ; \mathrm{X}_{\mathrm{jk}}$ the vector of yearlevel covariates; $\beta_{2}$ the coefficients for covariates $\mathrm{X}_{\mathrm{jk}} ; \mathrm{X}_{\mathrm{k}}$ the vector of farm-level covariates; $\beta_{3}$ the coefficients for covariates $\mathrm{X}_{\mathrm{k}}$; $\mathrm{v}_{\mathrm{k}}$ the random effect to reflect residual variation between farms; and $\mathrm{u}_{\mathrm{jk}}$ the random effect to reflect residual variation between years.

2. Discrete time survival (frailty) model (time from calving to first case of CM during lactation). Data were coded such that for each week of lactation, a cow-dry period either had a first case of clinical mastitis $(\mathrm{CM}=1)$ or not $(\mathrm{CM}=0)$. The model took the form

$$
\begin{aligned}
& \mathrm{CM}_{\mathrm{tijk}} \sim \text { Bernoulli probability }\left(\text { mean }=\mu_{\mathrm{tijk}}\right) \\
& \operatorname{Logit}\left(\mu_{\mathrm{tijk}}\right)=\alpha+\log \mathrm{t}_{\mathrm{tijk}}+\log \mathrm{t}_{\mathrm{tijk}}^{2}+\log \mathrm{t}_{\mathrm{tijk}}^{3} \\
& +\log \mathrm{t}_{\mathrm{tijk}}^{4}+\beta_{1} \mathrm{X}_{\mathrm{ijk}}+\beta_{2} \mathrm{X}_{\mathrm{jk}}+\beta_{3} \mathrm{X}_{\mathrm{k}}+\mathrm{v}_{\mathrm{k}}+\mathrm{u}_{\mathrm{jk}}
\end{aligned}
$$

where $t$ is the week of lactation (to provide the baseline odds of CM over time; Yang and Goldstein, 2003) and other symbols are as described previously.

Model building proceeded as follows: the distributions of covariates were assessed and transformations or recategorization carried out as deemed appropriate on biological grounds. Each of the 350 covariates was examined individually, within the specified model framework, to investigate individual associations with $\mathrm{CM}$ while accounting for the data structure. Initial covariate assessment was carried out using MLwiN with penalized quasi-likelihood for parameter estimation (Rasbash et al., 2005). To avoid the potential biased estimates that can arise from quasi-likelihood methods (Browne and Draper, 2006), final models were selected 
using Markov chain Monte Carlo (MCMC) for parameter estimation in WinBUGS (Spiegelhalter et al., 2004). Covariates with a strong association with $\mathrm{CM}(P<0.05)$ were carried forward and modeled together. Covariates remained in the model when the $95 \%$ credibility intervals for the odds ratios did not include 1.00. Correlations between variables were explored and when a correlation existed between significant covariates, both were assumed to have a potential biological association with CM, even when only one could be included in the final model because of collinearity. The last step in model building was to individually reintroduce each covariate into the model to assess their effect on model parameters. This was carried out to ensure that previously discarded variables did not become significant when added to the more complex model. Interactions between significant covariates were tested and included when the $95 \%$ credibility intervals for the odds ratio of the interaction term did not include 1.00. Variation in the effects of fixed covariates between farms and years was tested and these terms remained in the model when there was a decrease in the deviance information criteria (Spiegelhalter et al., 2002), a method that takes into account both improved model fit (reduction in deviance) and the increased model complexity (effective number of parameters). The models were restructured to fit "dry period" within "cow" within "farm," but this provided a poorer model fit to the data and therefore was not used.

All of the MCMC analyses reported in this article used a burn-in of at least 2,000 iterations during which time model convergence had occurred. Parameter estimates were based on a minimum further 8,000 iterations. Investigation of model fit was made from plots of cumulated fitted probabilities and residuals (Green et al., 2004). Comprehensive details of MCMC modeling (Gilks et al., 1996; Spiegelhalter et al., 2004) and the methods adopted for this research (Green et al., 2004; Browne and Draper, 2006) have been described previously.

From the models of FCM30, predictions were made of the incidence of FCM30 for each farm-year, using posterior predictive assessments (Gelman et al., 1996). This method incorporates the full model posterior predictive distribution:

$$
\begin{aligned}
& \text { PREDICTED FCM30 } 0_{\mathrm{ijk}}(1=\mathrm{CM}, 0=\operatorname{not} \mathrm{CM}) \\
& \sim \text { Bernoulli probability }\left(\mathrm{P}_{\mathrm{ijk}}\right) \\
& \operatorname{Logit}\left(\mathrm{P}_{\mathrm{ijk}}\right)=\alpha+\beta_{1} \mathrm{X}_{\mathrm{ijk}}+\beta_{2} \mathrm{X}_{\mathrm{jk}}+\beta_{3} \mathrm{X}_{\mathrm{k}}+\mathrm{v}_{\mathrm{k}}+\mathrm{u}_{\mathrm{jk}}
\end{aligned}
$$

where $\mathrm{P}_{\mathrm{ijk}}$ is the predicted probability of FCM30 for cow-dry period $i$ of year $\mathrm{j}$ on farm $\mathrm{k}$ and PREDICTED $\mathrm{FCM}_{30}$ ijk is a draw from the Bernoulli distribution with probability $\mathrm{P}_{\mathrm{ijk}}$. All other parameters are described pre- viously (Eq. [1]). After model convergence, at each iteration of the MCMC process, the values of PREDICTED FCM $30_{\text {ijk }}$ were averaged across each farm-year thus providing a posterior prediction of the incidence of FCM30 for individual farm-years. Predicted incidence rates were compared with the observed data and displayed graphically to illustrate model performance. The capability of each model to identify farm-years with a high incidence (specified as an FCM30 >0.2 cases per cow), was estimated by calculating the positive and negative predictive values (Dohoo et al., 2003) of the model for this outcome.

\section{RESULTS}

A total of 8,710 cow-dry periods $(6,852$ cows) were used in the analysis of CM in cows housed for the dry period and 9,964 cow-dry periods (7,576 cows) in the analysis of CM in cows with dry periods at pasture. The mean number of cow-dry periods included per farm for housed cows was 167.5 (range: 12 to 493) and the mean number for cows at pasture was 191.6 (range: 43 to 597). The incidence rates of FCM30 for cows housed and at pasture for the dry period are illustrated in Figures 1 and 2. One farm did not have any cows housed for the dry period during $1 \mathrm{yr}$ of the study; therefore, there were 104 farm-years included with cows at pasture during the dry period and 103 farm-years with cows housed. The mean (median) incidence rate of FCM30 (cases per cow at risk) for housed cows was 0.17 (0.16) and for those at pasture was $0.15(0.15)$. The relationship between the incidence rates of FCM30 for cows at pasture and for those housed, for each 103 farm-years, is illustrated in Figure 5. The correlation between these variables was moderate; the adjusted $\mathrm{R}^{2}$ was $35.4 \%$.

The Kaplan-Meier plots depicting survival to the first case of CM during lactation are presented in Figures 3 and 4 and illustrate the variation in rates of $\mathrm{CM}$ between different farm-years.

\section{Models of Clinical Mastitis}

The final models are presented in Tables 1 to 4 . As well as variability between farm-years and farms in the underlying rate of the first case of $\mathrm{CM}$, additional variability in first-case $\mathrm{CM}$ was identified between farms for first-parity cows and this term was incorporated in the final models. For housed cows, explanatory covariates that were correlated with significant covariates in the final models but that could not be fit because of collinearity were routine body condition scoring of cows at drying off (protective), good drainage in the early dry-cow cubicle accommodation (protective), mat- 


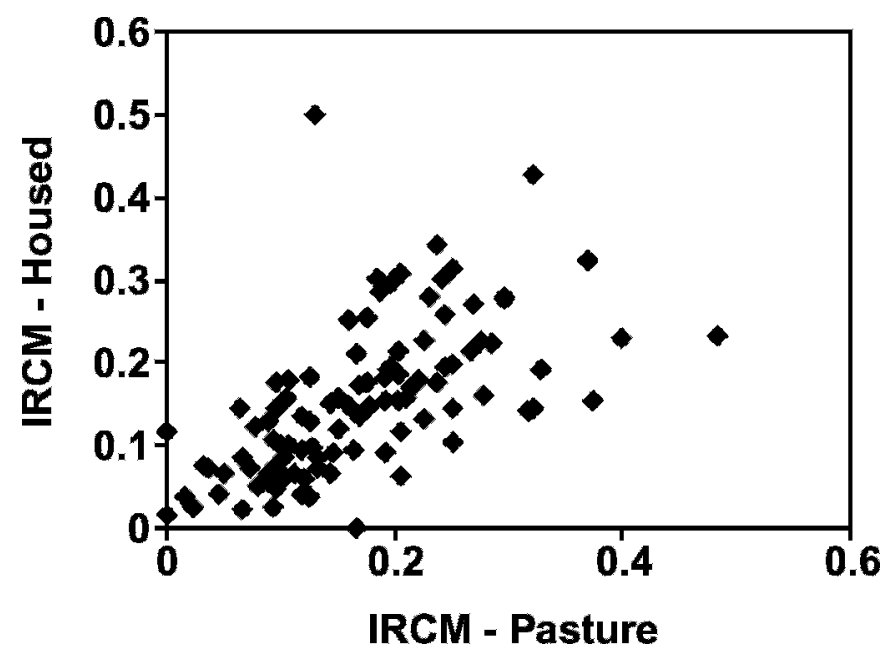

Figure 5. Scatter plot of the incidence rates of the first case of clinical mastitis in the first $30 \mathrm{~d}$ of lactation for cattle at pasture during the dry period (IRCM-Pasture; cases per cow at risk) and cattle housed during the dry period (IRCM-Housed; cases per cow at risk). tresses used on dry-cow cubicle surfaces (protective), disinfection of the close-up cow cubicle beds (protective), and housing the transition cows with the milking cows (increased risk). One covariate was correlated with significant covariates in the models for cows at pasture; this was ensuring that cows stood for 30 min after administration of the dry-cow treatment (protective).

Two cow-level covariates were associated with an increased risk of a first case of CM in all models; parity and SCC. The SCC status was initially modeled using categories of 20,000 cells $/ \mathrm{mL}$ at each of the 3 test-day readings before drying off. Only cell counts $\geq 200,000$ cells/mL were significantly associated with an altered risk of $\mathrm{CM}$, and the final categorization incorporated cows with any cell count $\geq 200,000$ cells $/ \mathrm{mL}$ within 90 $d$ of drying off (all cows had a minimum of 2 SCC readings in this period). No effect on CM was identified from cow yield before drying off (either the last recorded yield or 305-d lactation yield).

At the farm level, factors associated with altering the risk of a first case of CM could generally be grouped according to the timing of the event: drying off, early dry period, late (transition) dry period, and calving pe-

Table 1. Parameter estimates from the multilevel Bernoulli model with first case of clinical mastitis within $30 \mathrm{~d}$ of calving as the response, for cows housed during the dry period (model 1)

\begin{tabular}{|c|c|c|c|c|c|}
\hline \multirow[b]{2}{*}{ Model terms } & \multirow{2}{*}{$\begin{array}{l}\text { Cow dry } \\
\text { periods, } \\
n\end{array}$} & \multirow[b]{2}{*}{ Coefficient } & \multirow{2}{*}{$\begin{array}{l}\text { Odds } \\
\text { ratio }\end{array}$} & \multicolumn{2}{|c|}{$\begin{array}{l}\text { 95\% Credibility } \\
\text { interval }\end{array}$} \\
\hline & & & & $2.5 \%$ & $97.5 \%$ \\
\hline Intercept & & -0.95 & & & \\
\hline Parity $>4$ & 2,234 & & Reference & & \\
\hline Parity 1 & 1,983 & & 0.41 & 0.27 & 0.62 \\
\hline Parity 2 & 1,849 & & 0.51 & 0.43 & 0.62 \\
\hline Parity 3 & 1,434 & & 0.64 & 0.53 & 0.76 \\
\hline Parity 4 & 1,210 & & 0.72 & 0.60 & 0.86 \\
\hline All SCC $\leq 199,000$ cells $/ \mathrm{mL}$ within $90 \mathrm{~d}$ before drying off & 2,838 & & Reference & & \\
\hline One or more SCC $>199,000$ cell $/ \mathrm{mL}$ within $90 \mathrm{~d}$ before drying off & 3,507 & & 1.33 & 1.15 & 1.54 \\
\hline Less than 2 SCC readings available within $90 \mathrm{~d}$ before drying off & 2,365 & & 1.00 & 0.72 & 1.38 \\
\hline $\begin{array}{l}\text { Cows do not remain standing for } 30 \text { min after administration of dry } \\
\text { cow treatments }\end{array}$ & 1,743 & & Reference & & \\
\hline Cows remain standing for $30 \mathrm{~min}$ after administration of dry cow treatments & 6,967 & & 0.70 & 0.55 & 0.90 \\
\hline Do not reduce the milk yield of high-yielding cows before drying off & 6,561 & & Reference & & \\
\hline Reduce the milk yield of high-yielding cows before drying off & 2,149 & & 1.58 & 1.25 & 2.00 \\
\hline Do not disinfect cubicle bedding in early dry period & 1,439 & & Reference & & \\
\hline Disinfect cubicle bedding in early dry period & 2,231 & & 0.64 & 0.45 & 0.92 \\
\hline $\begin{array}{l}\text { Disinfection of cubicle bedding in early dry period not applicable } \\
\text { (straw yard systems) }\end{array}$ & 5,040 & & 1.45 & 1.07 & 1.98 \\
\hline Transition cows bedded on cubicles without mattresses & 913 & & Reference & & \\
\hline Transition cows bedded on cubicles with mattresses & 407 & & 0.25 & 0.10 & 0.59 \\
\hline No transition cow cubicles & 7,390 & & 0.81 & 0.56 & 1.17 \\
\hline Calving pens cleaned out after each calving & 2,023 & & Reference & & \\
\hline Calving pens cleaned out daily & 1,011 & & 0.62 & 0.42 & 0.94 \\
\hline Calving pens cleaned less frequently than daily & 401 & & 0.61 & 0.35 & 1.03 \\
\hline Farms without calving pens (calving yards only) & 5,275 & & 0.72 & 0.54 & 0.97 \\
\hline Cows first foremilked $>6 \mathrm{~h}$ after calving & 1,404 & & Reference & & \\
\hline Cows first foremilked $\leq 6 \mathrm{~h}$ after calving & 6,951 & & 0.67 & 0.50 & 0.93 \\
\hline Cows first foremilked at a variety of times & 355 & & 0.65 & 0.33 & 1.26 \\
\hline Farm-year variance & & 0.06 & & 0.01 & 0.14 \\
\hline Farm-level variance & & 0.10 & & 0.00 & 0.21 \\
\hline Farm $\times$ parity 1 variance & & 0.36 & & 0.13 & 0.78 \\
\hline
\end{tabular}


Table 2. Parameter estimates from the multilevel Bernoulli model with first case of clinical mastitis within $30 \mathrm{~d}$ of calving as the response, for cows at pasture during the dry period (model 2)

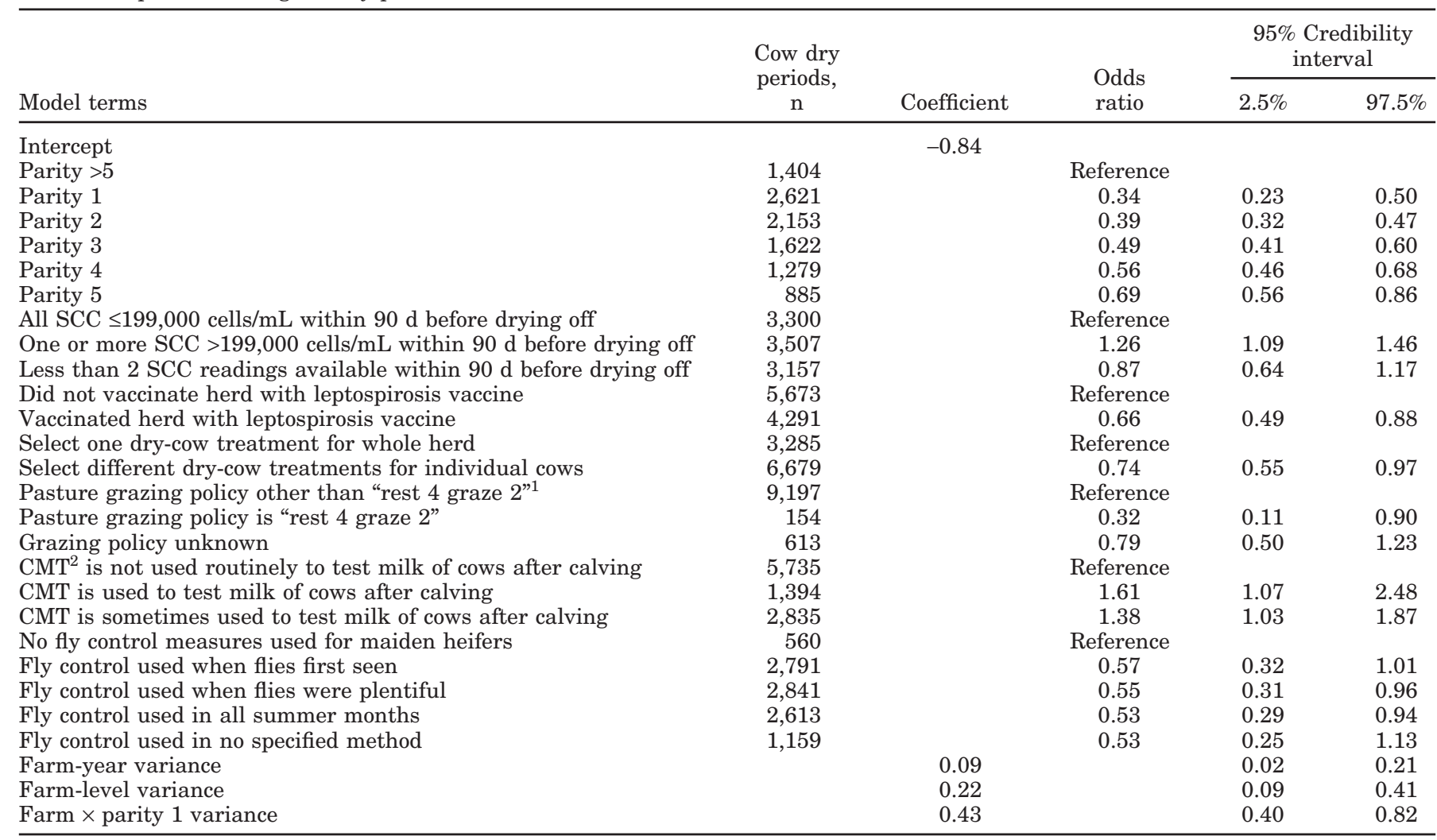

${ }^{1}$ Rest 4 graze 2 = a pasture rotation method such that dry cows graze the pasture for a maximum of 2 wk followed by stock not grazing the pasture for a minimum of $4 \mathrm{wk}$.

${ }^{2} \mathrm{CMT}=$ California Mastitis Test.

riod. An illustration of the main significant risk factors and correlated covariates, to summarize all models, is provided in Figure 6.

\section{Model Predictions}

The model predictions for the incidence rates of FCM30 are shown in Figures 7 and 8. Both models demonstrated a good ability to predict the incidence rate of FCM30 in a given farm-year, with the model predictions explaining over $85 \%$ of the variability in the observed data. Omission of outlying individual farms or farm-years did not have an important effect on any model parameters or overall biological interpretation. The positive and negative predictive values for identifying farm-years with an incidence rate of FCM30 $>0.2$ cases per cow, when cows were housed during the dry period, were 87.9 and $90.0 \%$, respectively. The equivalent positive and negative predictive values for farmyears when cows were at pasture were 84.6 and $96.1 \%$, respectively.

\section{DISCUSSION}

This is the first study to examine concurrently, and on a reasonably large scale, cow characteristics, farm facilities, and herd management strategies during the dry period that influence the rate of a first case of $\mathrm{CM}$ in the following lactation. A range of factors were associated with an increased risk and it is notable that they encompass a variety of times and events throughout the dry period, from the time of drying off to just after calving.

The cow characteristics associated with an increased rate of CM were not surprising. It is well established that cows with an SCC $\geq 200,000$ cells/mL are more likely to have an IMI than cows with a lower SCC (Dohoo and Meek, 1982). Because some of these infections may remain from the end of one lactation until the start of the next (failure to cure during the dry period), this group is likely to be at increased risk of CM during the following lactation.

Increasing parity increased the risk of $\mathrm{CM}$ and this has been noted previously (Green et al., 2002a; Whist 
Table 3. Parameter estimates from the multilevel discrete time survival model with first case of clinical mastitis as the response, for cows housed during the dry period (model 3 )

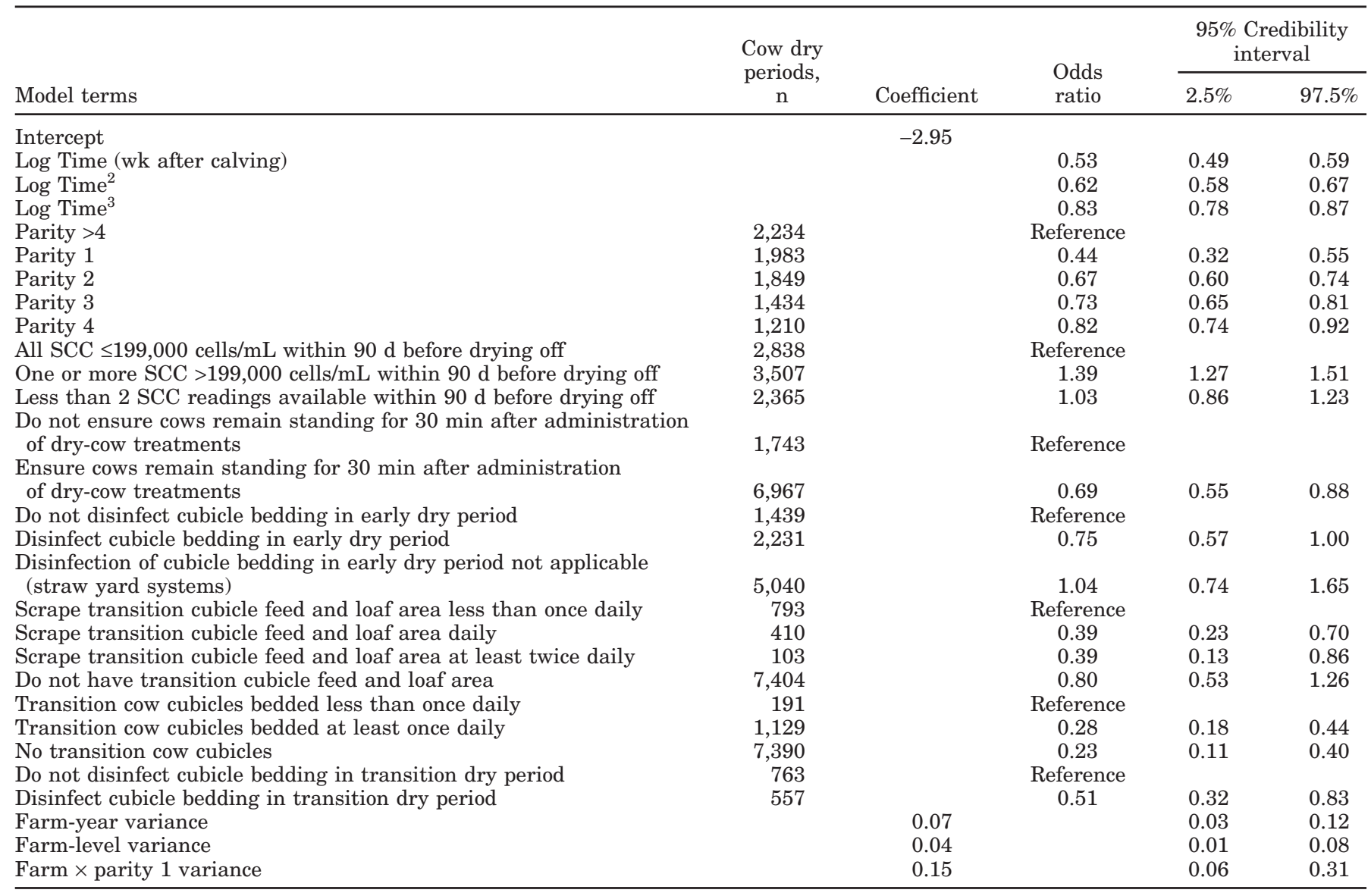

et al., 2006), although the reason for this association is not clear. It may be that there are anatomical changes in the teat over time that cause disruption of the natural defense mechanisms or there may be a systematic reduction in immune capability associated with aging (Paganelli et al., 2006; Weng, 2006) that increases susceptibility to infection. There may also be a risk that chronic infection survives through lactations as well as dry periods and results in an accumulated risk of recrudescence of clinical disease with increasing age. This consistent finding warrants further investigation.

Of the herd management factors associated with an increased rate of CM, many were related to hygiene; thus, the increased risk of CM probably resulted from increased pathogen challenge from the environment. Hygiene measures associated with the administration of dry-cow treatments, management of the early and late dry-period accommodations, and the calving area were all associated with an increased rate of CM. It is probable that attention to these practical procedures would have real benefits for mastitis control.
Some other herd management factors are worthy of more detailed consideration. Cows at pasture during the dry period and vaccinated with a leptospirosis vaccine were at reduced risk of CM compared with nonvaccinated herds. Bovine leptospirosis is not recognized as an important cause of bovine mastitis (National Mastitis Council, 1999; Bradley et al., 2007), and the reason for this association is not clear. It is possible that the vaccine confers some direct or indirect protective effect for mastitis, and this is worth further investigation. Leptospirosis vaccination was not associated with a reduced risk of CM when dry cows were housed; thus, it seems likely that any effect differs for cows housed or at pasture. Interestingly, some Leptospira serovars have been reported previously to have seasonal differences in infection patterns (Ellis et al., 1985; Guitian et al., 2001), and it seems that there is a seasonal difference in the effect of leptospirosis vaccination in this study. It is also possible that leptospirosis vaccination is a confounding covariate; administration of the vaccine could be associated with other (unidentified) farm factors that reduce the risk of $\mathrm{CM}$. 
Table 4. Parameter estimates from the multilevel discrete time survival model with first case of clinical mastitis as the response, for cows at pasture in the dry period (model 4$)$

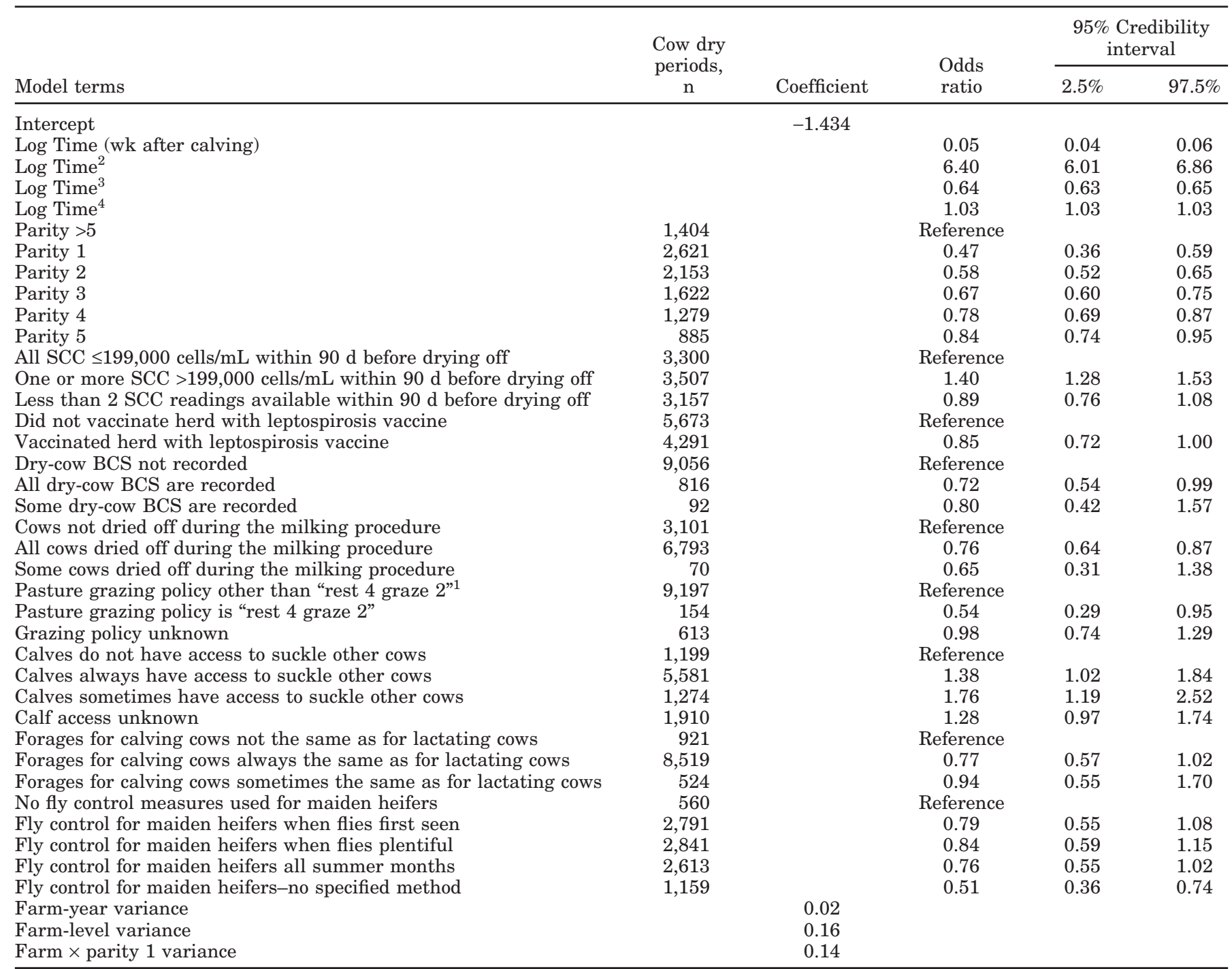

\footnotetext{
${ }^{1}$ Rest 4 graze 2 = a pasture rotation method such that dry cows graze the pasture for a maximum of 2 wk followed by stock not grazing
} the pasture for a minimum of $4 \mathrm{wk}$.

Another herd management policy associated with reduced CM for cows at pasture during the dry period was the application of different dry-cow regimens for different cows within a herd. The principle of selecting different dry-cow products for individual cows within a herd has been described for circumstances in the United Kingdom (Bradley et al., 2002; Green et al., 2002b) and is based on selecting an appropriate product for cows likely to be either infected or uninfected at drying off. The results of this study are of interest because they indicate that this slightly more complex approach to the application of dry-cow therapy does have a clinical benefit. In the current study, no individual pharmaceutical product was associated with a reduced rate of CM; thus, the principle of selecting an appropriate treatment for cows within a herd was more important than choosing any particular product. No farms omitted drycow treatments altogether for groups of cows, and thus the effect of "no treatment" could not be evaluated. It is unclear why the application of different dry-cow regimens for different cows within a herd was beneficial only for cows at pasture, and more research in this area would be enlightening.

Cows that were at pasture for the dry period had a lower rate of $\mathrm{CM}$ when farms had a pasture rotation policy of grazing a piece of land for a maximum of $2 \mathrm{wk}$ before allowing it to remain ungrazed for $4 \mathrm{wk}$. Many dairy herds in the United Kingdom prefer to keep dry 


\begin{tabular}{|c|c|}
\hline $\begin{array}{l}\text { Herd used leptospirosis vaccination } \\
\text { Fly control used in all summer months for heifers } \\
\text { Cows of lower parity }\end{array}$ & Overall factors \\
\hline SCC in last $90 \mathrm{~d}<200,000 \mathrm{cells} / \mathrm{mL}$ & Previous lactation \\
\hline $\begin{array}{c}\text { Stand for } 30 \text { min after administration of the } \\
\text { dry-cow treatment }\end{array}$ & \multirow{4}{*}{ Drying off } \\
\hline Select dry-cow treatment for individual cows & \\
\hline Body condition score cows & \\
\hline Dry off during the milking procedure & \\
\hline Disinfect cubicle bedding & \multirow{3}{*}{ Early dry period } \\
\hline Good drainage in cubicles & \\
\hline Mattresses used on cubicle surface & \\
\hline Disinfect cubicle bedding & \multirow{6}{*}{ Late dry period } \\
\hline Mattresses used on cubicle surface & \\
\hline Scrape feed and loafing area daily & \\
\hline Cubicles bedded at least once daily & \\
\hline Pasture grazing policy is "rest 4 graze 2" & \\
\hline Cows not housed with the milking herd & \\
\hline Calving pens cleaned out daily & \multirow{4}{*}{ Calving period } \\
\hline Cows first foremilked $\leq 6 \mathrm{~h}$ after calving & \\
\hline Forages always the same as for lactating cows & \\
\hline Calves do not have access to suckle other cows & \\
\hline
\end{tabular}

Figure 6. Summary of the major cow, farm, and management factors associated with a significantly reduced risk of clinical mastitis. Rest 4 graze 2 = a pasture rotation method such that dry cows graze the pasture for a maximum of 2 wk followed by stock not grazing the pasture for a minimum of 4 wk. 


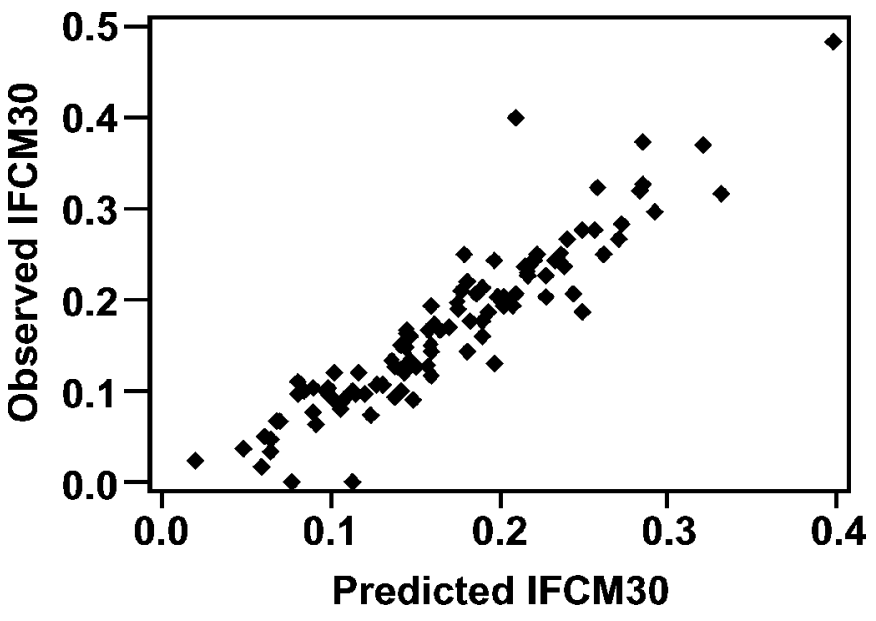

Figure 7. Correlation between model prediction and the observed incidence rate of the first case of clinical mastitis in the first $30 \mathrm{~d}$ of lactation (IFCM30; cases per cow at risk), in 103 farm-years, for cows housed during the dry period $\left(\mathrm{R}^{2}=85.8 \%\right)$.

cows at pasture in the belief that conditions are cleaner. These findings indicate that pasture contamination may occur and that this rotation policy might reduce challenge. Ecological issues surrounding mastitis pathogens that survive predominantly in the environment are not well defined. Although these pathogens are considered to prefer warm, wet, organic conditions (Hogan and Smith, 2003), exact survival times and infective doses under different conditions of temperature, humidity, and sunlight, for example, are poorly characterized. Further understanding in this area would help to improve environmental management for mammary health, particularly for cows at pasture.

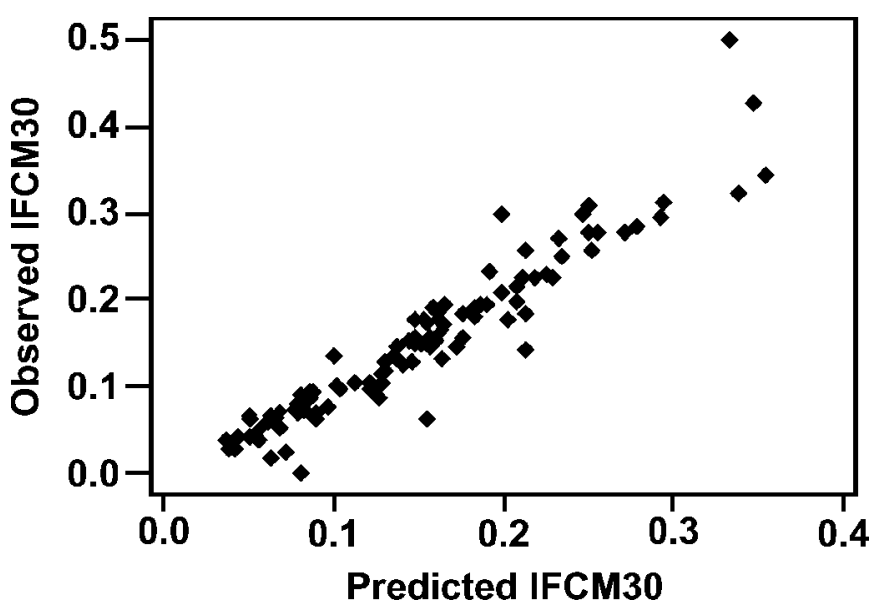

Figure 8. Correlation between model prediction and the observed incidence rate of the first case of clinical mastitis in the first $30 \mathrm{~d}$ of lactation (IFCM30; cases per cow at risk), in 104 farm-years, for cows at pasture during the dry period $\left(\mathrm{R}^{2}=87.9 \%\right)$.
Cows that were at pasture for the dry period, and that were on farms that carried out routine body condition scoring at drying off or that fed the same forages for the calving cows as for lactating cows, experienced a reduced rate of $\mathrm{CM}$ compared with herds that did not follow these policies. These farm policies may be beneficial to mastitis control indirectly, through limiting of negative energy status, a link that has previously been reported (Suriyasathaporn et al., 2000).

Cows that were on farms with a policy of foremilking cows within $6 \mathrm{~h}$ of calving had a reduced rate of CM compared with farms that foremilked cows later after calving. The reason for this is unclear. A possible link with CM could be a "flushing" effect, with infections being removed by forestripping before clinical signs appear. Similarly, cows had an increased rate of CM on farms where calves had access to suckle from cows other than their dam. A hypothesis in this case could be that access to suckle from more than one cow allows pathogens to spread between cows.

The use of a California Mastitis Test in cows after calving is commonly recommended in the United Kingdom. In this study, cows on farms that used this practice had an increased rate of CM. This may be a result of improved mastitis detection, reverse causality (an increased rate of $\mathrm{CM}$ after calving resulting in a greater probability of use of the test), or it is possible that overdiagnosis occurs with this test; that is, cows that may self cure are treated as clinical cases based on a positive California Mastitis Test. Alternatively, it is possible that the test was not always conducted with adequate hygiene procedures and thereby caused an increased risk of new IMI. This finding is worthy of further investigation.

One herd management practice that was unexpectedly associated with an increased rate of $\mathrm{CM}$ was the general policy of reducing cow milk yield before drying off. An increased milk yield at drying off has been previously reported to result in an increased risk of CM (Dingwell et al., 2004), and it therefore could be expected that the policy of reducing milk yield before drying off would be protective. Furthermore, in the current study, both individual cow yield at the test day before drying off and 305-d yield during the previous lactation were tested as possible risk factors, but neither influenced the rate of CM. It may be, however, that the magnitude of milk yield at the point of drying off is important in increasing the risk of subsequent $\mathrm{CM}$, and such an effect has been reported recently in a singleherd study of IMI after calving (Rajala-Schultz et al., 2005). Because milk yield at the point of drying off was not measured in the current study, firm conclusions about milk yield and CM are difficult to draw. It would be of interest to conduct further multiple-herd studies 
to assess the extent of between-herd variability in the effect of milk yield at the point of drying off and subsequent mammary gland health.

An aspect of herd management that did not have a measurable effect on rates of CM was straw yard management, despite the fact that more than half of cows housed during the dry period were kept in straw yards. A variety of issues were considered including cleaning out times, bedding management, and stocking density. Therefore, hypotheses for improving yard management cannot be generated from these data.

The predictions of rates of CM made from the final models indicated a good model fit and are encouraging for model interpretation. The relatively high correlation between predicted and observed rates of CM for each farm-year indicates that the variables incorporated in the final models were useful to explain differences in mastitis incidence. A plausible link between many of the risk factors identified in this study and the rate of $\mathrm{CM}$ is through an effect on the probability of infection during the dry or calving period leading to an increased risk of CM (Green et al., 2002a). Direct paths of causality between explanatory and response covariates, however, can only be inferred cautiously from cohort studies of this type.

Susceptibility of the bovine mammary gland to infection during the dry period is considered to be greatest in the days after drying off and in the 3 wk before calving (Bradley and Green, 2004), and results from this study indicate that the probability of infection can be influenced by cow and farm factors during this time. Thus, there seems to be a complex series of interrelationships; cow infection status at drying off, individual cow tendency to cure and to new infection, the influence of farm facilities, farm practices, and treatment strategies, as well as the probability of CM conditional upon infection status at calving. Therefore, to weigh decisions on prevention of CM from the dry period, probabilities and costs need to be attached appropriately to all these events so that farm-decision models can be developed. This would be a useful area of further research.

\section{CONCLUSIONS}

Combinations of cow characteristics, farm facilities, and herd management strategies during the dry period were associated with an increased rate of CM in lactation. Models incorporating these factors made a good prediction of the incidence rate of $\mathrm{CM}$ in the first 30 $d$ of lactation for different farm-years. The research indicated that dry-period management influences CM in the next lactation and has highlighted areas important for mastitis control.

\section{ACKNOWLEDGMENTS}

This research was funded by the Wellcome Trust; Martin Green is a Wellcome Trust intermediate clinical fellow. We would like to thank the Milk Development Council for funding initial research and National Milk Records (Chippenham, United Kingdom) for providing data. We are also very grateful to Laura Green, James Breen, and Katharine Leach for data collection, James Booth for his support, and all the farmers and their veterinary surgeons for their participation and cooperation.

\section{REFERENCES}

Berry, E., and J. E. Hillerton. 2002. The effect of an intramammary teat seal on new intramammary infections. J. Dairy Sci. 85:2512-2520.

Bradley, A. J., and M. J. Green. 2000. A study of the incidence and significance of intramammary enterobacterial infections acquired during the dry period. J. Dairy Sci. 83:1957-1965.

Bradley, A. J., and M. J. Green. 2001. An investigation of the impact of intramammary antibiotic dry cow therapy on clinical coliform mastitis. J. Dairy Sci. 84:1632-1639.

Bradley, A. J., and M. J. Green. 2004. The importance of the nonlactating period in the epidemiology of intramammary infection and strategies for prevention. Vet. Clin. North Am. Food Anim. Pract. 20:547-568.

Bradley, A. J., J. N. Huxley, and M. J. Green. 2002. A rational approach to dry cow therapy. II. Making logical treatment decisions. In Pract. 25:12-17.

Bradley, A. J., K. A. Leach, J. E. Breen, L. E. Green, and M. J. Green. 2007. A survey of the incidence rate and aetiology of mastitis on dairy farms in England and Wales. Vet. Rec. 160:253-258.

Browne, W. J., and D. Draper. 2006. A comparison of Bayesian and likelihood-based methods for fitting multilevel models. Bayesian Anal. 1:473-514.

Dingwell, R. T., K. E. Leslie, Y. H. Schukken, J. M. Sargeant, L. L. Timms, T. F. Duffield, G. P. Keefe, D. F. Kelton, K. D. Lissemore, and J. Conklin. 2004. Association of cow and quarter-level factors at drying-off with new intramammary infections during the dry period. Prev. Vet. Med. 30:75-89.

Dohoo, I. R., W. Martin, and H. Stryhn. 2003. Veterinary Epidemiologic Research. AVC Inc., Charlottetown, Canada.

Dohoo, I. R., and A. H. Meek. 1982. Somatic cell counts in bovine milk. Can. Vet. J. 23:119-125.

Ellis, W. A., J. J. O'Brien, D. G. Bryson, and D. P. Mackie. 1985. Bovine leptospirosis: Some clinical features of serovar Hardjo infection. Vet. Rec. 117:101-104.

Collett, D. 1994. Modelling Survival Data in Medical Research. CRC Press, Boca Raton, FL.

Gelman, A., X. L. Meng, and H. Stern. 1996. Posterior predictive assessment of model fitness via realized discrepancies. Stat. Sinica 6:733-807.

Gilks, W. R., S. Richardson, and D. J. Spiegelhalter. 1996. Markov Chain Monte Carlo in Practice. Chapman and Hall, London, UK.

Goldstein, H. 1995. Multilevel Statistical Models. 2nd ed. Edward Arnold, London, UK.

Green, M. J., P. R. Burton, L. E. Green, Y. H. Schukken, A. J. Bradley, E. J. Peeler, and G. F. Medley. 2004. The use of Markov chain Monte Carlo for analysis of correlated binary data: Patterns of somatic cells in milk and the risk of clinical mastitis in dairy cows. Prev. Vet. Med. 64:157-174.

Green, M. J., L. E. Green, A. J. Bradley, P. R. Burton, Y. H. Schukken, and G. F. Medley. 2005. Bacterial isolates in the dry bovine mammary gland: Prevalence and associations. Vet. Rec. 156:71-77.

Green, M. J., L. E. Green, G. F. Medley, Y. H. Schukken, and A. J. Bradley. 2002a. Influence of dry period bacterial intramammary 
infection on clinical mastitis in dairy cows. J. Dairy Sci. 85:2589-2599.

Green, M. J., J. N. Huxley, and A. J. Bradley. 2002b. A rational approach to dry cow therapy. I. Background and current perspectives. In Pract. 24:582-587.

Green, M. J., K. A. Leach, J. E. Breen, L. E. Green, and A. J. Bradley, 2007. A national intervention study of mastitis control on dairy herds in England and Wales. Vet. Rec. 160:287-293.

Guitian, F. J., F. J. Garcia-Pena, J. Oliveira, M. L. Sanjuan, and E. Yus. 2001. Serological study of the frequency of leptospiral infections among dairy cows in farms with suboptimal reproductive efficiency in Galicia, Spain. Vet. Microbiol. 80:275-284.

Hogan, J., and L. K. Smith. 2003. Coliform mastitis. Vet. Res. 34:507-519.

Huijps, K., and H. Hogeveen. 2007. Stochastic modeling to determine the economic effects of blanket, selective, and no dry cow therapy. J. Dairy Sci. 90:1225-1234.

Huxley, J. N., M. J. Green, L. E. Green, and A. J. Bradley. 2002. Evaluation of the efficacy of an internal teat sealer during the dry period. J. Dairy Sci. 85:551-561.

National Mastitis Council. 1999. Laboratory Handbook on Bovine Mastitis. National Mastitis Council Inc., Madison, WI.

Neave, F. K., F. H. Dodd, and E. Henriques. 1950. Udder infections in the dry period. J. Dairy Res. 17:37-49.

Oliver, S. P., and B. A. Mitchell. 1983. Susceptibility of the bovine mammary gland to infections during the dry period. J. Dairy Sci. 66:1162-1166.

Paganelli, R., A. Di Iorio, A. Cherubini, F. Lauretani, C. Mussi, S. Volpato, M. Abate, G. Abate, and L. Ferrucci. 2006. Frailty of older age: The role of the endocrine-immune interaction. Curr. Pharm. Des. 12:3147-3159.
Rajala-Schultz, P. J., J. S. Hogan, and K. L. Smith. 2005. Association between milk yield at dry-off and probability of intramammary infections at calving. J. Dairy Sci. 88:577-579.

Rasbash, J., W. J. Browne, M. Healy, B. Cameron, and C. Charlton. 2005. MLwiN Version 2.02, Multilevel Models Project. Institute of Education, University of London, London, UK.

Robert, A., H. Seegers, and N. Bareille. 2006. Incidence of intramammary infections during the dry period without or with antibiotic treatment in dairy cows-A quantitative analysis of published data. Vet. Res. 37:25-48.

Smith, K. L., D. A. Todhunter, and P. S. Schoenberger. 1985. Environmental pathogens and intramammary infection during the dry period. J. Dairy Sci. 68:402-417.

Spiegelhalter, D. J., N. G. Best, B. P. Carlin, and A. van der Linde. 2002. Bayesian measures of model complexity and fit (with discussion). J. R. Stat. Soc. Ser. B Stat. Methodol. 64:583-640.

Spiegelhalter, D. J., A. Thomas, and N. Best. 2004. WinBUGS Version 1.4.1. MRC Biostatistics Unit, Cambridge, UK.

Suriyasathaporn, W., C. Heuer, E. N. Noordhuizen-Stassen, and Y. H. Schukken. 2000. Hyperketonemia and the impairment of udder defense: A review. Vet. Res. 31:397-412.

Todhunter, D. A., K. L. Smith, J. S. Hogan, and P. S. Schoenberger. 1991. Gram-negative bacterial infections of the mammary gland in cows. Am. J. Vet. Res. 52:184-188.

Weng, N. P. 2006. Aging of the immune system: How much can the adaptive immune system adapt? Immunity 24:491-494.

Whist, A. C., O. Østerås, and L. Sølverød. 2006. Clinical mastitis in Norwegian herds after a combined selective dry-cow therapy and teat-dipping trial. J. Dairy Sci. 89:4649-4659.

Yang, M., and H. Goldstein. 2003. Modelling survival data in MLwiN 1.20. Centre for Multilevel Modelling, Institute of Education, University of London, London, UK. 